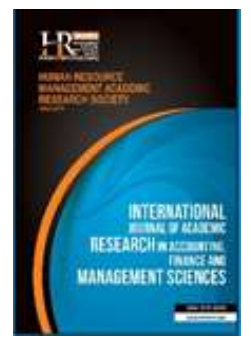

International Journal of Academic Research in Accounting, Finance and Management Sciences

Vol. 9, No.3, July 2019, pp. 305-311

E-ISSN: 2225-8329, P-ISSN: 2308-0337

(C) 2019 HRMARS

www.hrmars.com

To cite this article: Mohaiyuddin, N., Kardi, N., Arip, M.A.S.M. (2019). Reliability Analysis of Students Entrepreneurship Career Determination Module (ECDM) Based on Cognitive Behavioral Therapy Approach (CBT), International Journal of Academic Research in Accounting, Finance and Management Sciences 9 (3): 305-311

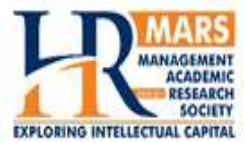

\title{
Reliability Analysis of Students Entrepreneurship Career Determination Module (ECDM) Based on Cognitive Behavioral Therapy Approach (CBT)
}

\author{
Norasyikin Mohaiyuddin ${ }^{1}$, Nordin Kardi ${ }^{2}$, Mohammad Aziz Shah Mohamed Arip ${ }^{3}$ \\ 1,2Sultan Azlan Shah University, Kuala Kangsar, Perak \\ ${ }^{3}$ Sultan Idris Education University, Tanjung Malim, Perak
}

\begin{abstract}
The purpose of this study is to obtain the reliability of the content of Entrepreneurship Career Determination Module (ECDM) based on the Cognitive Behavioral Therapy (CBT) approach. Cognitive Behavioral Therapy has a treatment approach towards more positive cognitive, trust and behavioral restructuring. The sample consists of 35 first degree students who were in their fifth semester at Sultan Azlan Shah University. Questionnaires of module reliability were constructed based on the steps that were set for each activity. The data obtained were analyzed using SPSS to see the value of Cronbach alpha of this module. The results of the pilot study show that this module has a high reliability value of .964. The implications of this study are also discussed for the purpose of further study in this area.

Key words Reliability Analysis, Entrepreneurship Career Determination, Module, Cognitive Behavioral Therapy, Entrepreneurship Career Determination Module

Received: 20 Sep $2019 \quad$ C The Authors 2019

Revised: 21 Oct 2019 Published by Human Resource Management Academic Research Society (www.hrmars.com)

Accepted: 29 Oct 2019 This article is published under the Creative Commons Attribution (CC BY 4.0) license. Anyone may Published Online: 01 Nov 2019 reproduce, distribute, translate and create derivative works of this article (for both commercial and non-commercial purposes), subject to full attribution to the original publication and authors. The full terms of this license may be seen at: http://creativecommons.org/licences/by/4.0/legalcode
\end{abstract}

\section{Introduction}

In Malaysia, career in entrepreneurship is not a career choice of graduates after graduation. Entrepreneurship is the second or last choice and at the same time indicating that career in entrepreneurship is not a preferred choice among students today (Norasmah, 2005). This scenario is different from graduates in developed countries who have high inclination to be involved in entrepreneurship. Involvement in entrepreneurship has become a contributing factor in the country's economic growth.

According to Hisrich et al. (2008), the key to student's involvement in entrepreneurship depends on the behavior in choosing entrepreneurship career itself. The main factor which influenced the behavior to choose the option is the high tendency or interest to venture into the field. This is followed by the identification of the opportunities that existed subsequently the decision-making process to explore available opportunities in entrepreneurship is another factor. In Malaysia the level of behavior to choose a career in entrepreneurship is still quite low (Esa et al., 2013; Norasmah et al., 2012). Entrepreneurship is only the second and last choice among students due to the lack of awareness of the potential in the field of entrepreneurship (Norasmah, 2005; Norasmah and Salmah, 2011).

Despite various efforts being undertaken by the government to foster the interest, the tendency of students to get involved in entrepreneurship activity is still low due to poor perceptions resulting from the difficulties and failures in the field of entrepreneurship (Zainol et al., 2012). It can therefore be concluded 
that if a student has a positive perception towards entrepreneurship career then they are seen to have high potential to venture into the field. This can be seen through the behaviors that they have on the entrepreneurship career, for example, their desire to seek advice and to be active in entrepreneurship activities held within the universities (Ab. Aziz and Zakaria, 2004; Norasmah and Faridah, 2010; Norasmah et al., 2012).

The primary responsibility of university is how to inculcate entrepreneurship determination amongst students during their studies to prepare them in the self-marketability as a job creator after graduation from the university. This is supported by (Branchet et al., 2011), that preparing and cultivating entrepreneurship determination towards students with the aim of providing them with career marketability is an important factor within the general public.

\section{Literature review}

Each module that has been developed needs to run a pilot study to obtain the value of realibility. Modules that do not have high validity values are not suitable to be implemented in experimental studies.

Most of the module construction studies are also more focused on vocational career in the job market alone. For entrepreneurship career, more focus was given on the high impact educational practices by applying entrepreneurial elements across the curriculum and field of study. Nevertheless, the rate of student engagement with entrepreneurial activity in the public and private institutions of higher learning remains low although various entrepreneurship programs are implemented. To date, only $2.5 \%$ of graduates are involved in entrepreneurship after graduation and this is critical if compared with the rate of unemployment amongst graduates each year (Ministry of Higher Education, 2016).

Until now, no other study has been conducted in relation to the construction of the structured modules in the context of entrepreneurship career which used a counseling psychology approach that is the Cognitive Behavioral Therapy group guidance to enhance career determination in this field. Cognitive Behavioral Therapy is used as the basis because of the interconnectedness between cognitive, emotional and behavioral suitability that conforms to the determination, attitude, and self-efficacy constructs themselves which are also the cognitive elements. Furthermore, cognitive elements are very important in entrepreneurial career (Baron, 2004). In Cognitive Behavioral Therapy, when negative cognitive elements can be changed through the techniques in this therapeutic approach, changes also affect emotions and behaviors to become positive (Beck, 2011). If constructs on the determination are positive, then the potential for behavior to implement will increase (Ajzen, 1991).

\subsection{Integration of Cognitive Behavioral Therapy and Planned Behavioral Theory in ECDM-CBT}

This Entrepreneurship Career Module covers eight sessions of group treatment as a student entrepreneurial determination intervention. This module starts with the first session i.e. introductory session and the introduction of ECDM-CBT. The follow sessions are the process of strengthening the entrepreneurial determination of the students based on the approach of Cognitive Behavioral Therapy (CBT). The eighth session i.e. the last session where the overall conclusion in relation to the activity throughout the group's guidance is made. This includes sharing of feelings and experiences.

In order to enhance the entrepreneurial determination of the students, three main constructs of the Theory of Planned Behavioral (TPB) by Ajzen (1975), were used as the basis of constructs for each session. In summary, from the second session to the seventh session, the CBT approach was used to transform the three major PBT constructs towards a more positive direction i.e. attitude, subjective norms and perceived behavioral control or self-efficacy (SNEK).

Table 1 below shows the integration between CBT technique and Theory of Planned Behavioral (TPB) to develop Entrepreneurship Career Module.

Table 1 below shows the sessions and activities which have been developed for the Entrepreneurship Career Determination Module (ECDM). The researcher has constructed eight sessions with 20 activities and seven homework assignments. Session 1: Introductory sessions with members of the group (Activity 1: SelfIntroduction \& orientation) Session 2: Identifying ECGG Based on TPB \& CBT And Analyzing Entrepreneurial Psychological Barriers (Activity 1: Magic Triangle \& SNEK, Activity 2: Mind Wall, Activity 3: My Wheel of Fortune) Session 3: Analyzing ABC, Critical Events, Beliefs and Effects (Activity 1: Let's begin with ABC, 
Activity 2: My ABC, Activity 3: What is the Replacement), Session 4: Handling irrational Negative perception towards Entrepreneurship (Activity 1: Table Tower, Activity 2: What are they Saying, Activity 3: I Then and Now. Session 5: Handling Irrational Negative Emotions towards Entrepreneurship (Activity 1: Challenges, Expectations and Actions, Activity 2: "Keramat Hidup", Activity 3: Emotions \& Solutions) Session 6: Handling Irrational Negative Behavior towards Entrepreneurship Activity 1: Let's do it now, Activity 2: Value of a piece of Marshmallow, Activity 3: Behind the Tycoon Empire) Session 7: Analyzing Reconsiderations. Activity 1: Let's Reconsider! Activity 2: I'm Positive. Session 8: Strengthening Positive Thinking \& Termination, Activity 1: Strengthening positive thinking and rational beliefs of members towards entrepreneurial activity, Activity 2: Termination.

Table 1. Integrated Approach of Cognitive Behavioral Therapy and Planned Behavioral Theory in ECDM

Group session \& period

Session 1: Group members introduction

(60 minutes)

Session 2: Getting to know ECGG

Based on PBT \& CBT And

Analyzing Entrepreneurial

Psychological Barriers (90

minutes)

Session 3: Analyzing ABC, Critical Events, Trust and Effect (90 minutes)

Session 4: Handling Irrationality in Negative Perception Towards Entrepreneurship

Session 5 : Handling Irrational Negative Emotion Towards Entrepreneurship

Session 6: Handling Irrational Negative Behavior Towards Entrepreneurship

Session 7: Analyzing and Reconsideration

Session 8: Strengthening Positive Thinking \& Termination

\section{Activity}

Constructs in PBT

CBT Approach

Activity 1 : Self-Introduction and

orientation (60 minutes)

Activity 1: Magic Triangle \& SNEK

(30 minutes)

Activity 2: Mind Wall (30 minutes)

Activity 3: My Wheel of Fortune

(30 minutes)

Activity 1: Let's begin with $A B C$

(30 minutes)

Activity 2: My $A B C$

(30 minutes)

Activity 3: What is the replacement?

(30 minutes)

Activity 1: Table Tower

(30 minute)

Activity 2: What are they saying?

(30 minutes)

Activity 3: I Then and Now

(30 minutes)

Activity 1: Challenges, Expectations and

Actions

Activity 2 : "Keramat Hidup"

Activity 3: Emotion \& Solution

Activity 1: Let's Do It Now

Activity 2:

Value of a piece of Marshmallow

Activity 3:Behind the Tycoon Empire

Activity 1: Let's Reconsider!

Activity 2: I am Positive

Activity 1: Strengthening positive thinking and rational beliefs of members towards Entrepreneurship activities
Attitude, Subjective 1. PsychoEducation and Norms and Self- Homework

Efficacy

2. PsychoEducation and Homework

3. PsychoEducation and Homework

Attitude, Subjective 1.PsychoEducation and Norms and Self- Homework

Efficacy

2. PsychoEducation and Homework

3. Guided Discovery

(GDT) Technique

Attitude,

1.Metaphor of

Guided Discovery

Subjective Norms

2. PsychoEducation and Homework

Self-Efficacy

3.Guided Discovery

Technique (GDT)

Attitude,

1. Guided Discovery Technique (GDT)

Subjective Norms

2. Play the Role

Self-Efficacy

3. Guided Discovery

Technique (GDT)

Attitude

1. Guided Discovery

Subjective Norms

2. Guided Discovery

Technique (GDT)

3. Modelling

Self-Efficacy

Bibliography

Attitude, and Self-

1. Guided Discovery

Technique (GDT)

2. PsychoEducation

Attitude, Subjective

Norms and Self-

Efficacy
Technique (GDT)

Technique (GDT) 


\subsection{Module Reliability}

Reliability testing is a test conducted to ensure that the instruments used are of high reliability and able to solve problems that may occur during the actual study (Ghazali, 2018). Reliability should also be tested on modules as done on test tools. This is because testing tools and modules constructed are both tools which were developed with specific objectives (Noah and Ahmad, 2005). The reliability test of this module aims to obtain information on the quality and modules used (Mahmud, 2017). In addition, reliability is also intended to see how far the student can follow the contents of the module (Rusell, 1974). For the purpose of evaluating this reliability, the coefficient value of module reliability based on module activity steps is found to have higher reliability coefficient value compared to the reliability coefficient value based on module objectives (Noah and Ahmad, 2005).

In this regard, the Survey of Entrepreneurship Career Determination Module (QECDM) questionnaire was developed by researchers based on the steps of each activity in the module to obtain the reliability of the MTKK. This QECDM has 120 question items and is administered to 35 students following this module in the pilot study.

\section{Study Objective}

1. Review the reliability value of the session and activities of the Entrepreneurship Career Determination Module (ECDM-CBT)

2. Review the reliability of ECDM-CBT Module content

\section{Methodology of research}

This study is a quantitative survey study. The findings of this study were obtained after a pilot study was conducted on a group of research subjects who possess almost the same characteristics as the subjects of the actual study. This reliability test is also a test conducted to ensure that the instruments used are of high reliability and able to solve problems which may occur during the actual study (Ghazali, 2018). The purpose of this study is to obtain the value of Cronbach alpha modules as a whole and the value of reliability according to session and activity

\section{Findings}

Table $2(A)$. Reliability test findings for each session and ECDM activities

\begin{tabular}{llc}
\hline \multicolumn{1}{c}{ Session } & \multicolumn{1}{c}{ Activity/Filling } & A value \\
\hline Session 1: & Activity 1: Self Introduction \& orientation & .712 \\
Group members' introduction & & \\
Session 2: Getting to know ECGG Based on & Activity 1: Magic Triangle \& SNEK & .798 \\
PBT \& CBT And Analyzing Entrepreneurial & Activity 2: The Mind Wall & .766 \\
Psychological Barriers & Activity 3: My Wheel of Fortune & .786 \\
Session 3: Analyzing ABC, Critical Events, Trust & Activity 1: Let's begin with ABC & .793 \\
and Effect & Activity 2: My ABC & .711 \\
& Activity 3: What is the Replacement & .723 \\
Session 4: Handling Irrational Negative & Activity 1: Table Tower & .836 \\
Perception Towards Entrepreneurship & Activity 2: What Are They Saying? & .733 \\
& Activity 3: I Then and Now & .777 \\
Session 5: Handling Irrational Negative & Activity 1: Challenges, Expectations and Actions & .878 \\
Emotion Towards Entrepreneurship & Activity 2: "Keramat Hidup" & .842 \\
& Activity 3: Emotions \& Solutions & .841 \\
\hline
\end{tabular}


Table 2 (B). Reliability test findings for each session and ECDM activities

\begin{tabular}{lll}
\hline \multicolumn{1}{c}{ Session } & \multicolumn{1}{c}{ Activity/Filling } & A value \\
\hline Session 6: Handling Irrational & Activity 1: Let's Do It Now & .867 \\
Negative Behavior & Activity 2: Value of A Piece of Marshmallow & .819 \\
Towards Entrepreneurship & Activity 3: Behind the Tycoon Empire & .828 \\
Session 7: Analyzing Considerations & Activity 1: Let's Reconsider! & .884 \\
& Activity 2: I'm Positive & .835 \\
Session 8: Strengthening Positive & Activity 1: Positive Thinking, Positive Emotions And & .786 \\
Thinking \& Termination & Positive Behavior. & .908 \\
& Activity 2: Termination & \\
\hline
\end{tabular}

\section{Discussions}

The table above shows the reliability value of ECDM which is higher than 0.6. This is in line with the views of Pallant (2001) and Mohd Majid (1998) which state that the reliability coefficient value of test equipment must be at least .60. All of the above activities recorded alpha value of more than .06 with a minimum value of .711 in activity 2 session 3 . In addition, there are 10 other activities which were at the alpha value of above .08 while the highest is at .928. The Table Tower activitie's alpha value was .836, while Challenges, Expectations and Actions activity achieved the alpha value of .878, "Keramat Hidup" Activity the alpha value was .842, Emotions and Solutions alpha was at .841, Let's Do It Now activity was .867, Value of a piece of Marshmallow activity was at .819 , Behind the Tycoon Empire activity is .828, Let's reconsider activity achieved the alpha value of $.884, \mathrm{I}$ am Positive activity is .835 , Positive Thinking, Positive Emotions And Positive Behavior activity was at .786 and alpha value for Termination is at .908 . The overall reliability value of this module was at .964 .

\section{Study Implications}

The main focus of this study is to obtain the reliability value of the module through pilot study which has been done. This is the second stage of pilot study after the validity value of this module is devised from the assessment of the panel of experts. The results of this study show that this module recorded high reliability value and this encourages the researcher to apply the ECDM-CBT in giving guidance to nurture the student's entrepreneurship career determination. Therefore, this study has to construct helpful highreliability career determination module, using a counseling psychology approach i.e. based on Cognitive Behavioral Therapy. The approach of the guiding group as well as CBT psycho-education is an approach that can be used to foster entrepreneurship career determination among university students. It is hoped that the success of cultivating this entrepreneurial career determination will help students in their career planning during their studies, this module may also be used to help student to create job opportunities.

\section{Study Recommendations}

Based on the findings of the study, a few recommendations are, therefore, put forward as follows:

1. An intervention approach that incorporates the Cognitive Behavioral Therapy (CBT) approach and Theory of Planned Behavior (TPB) can be carried out by way of experimental study to see the impact of Entrepreneurship Career Determination Module (ECDM) in terms of addressing the low entrepreneurial career determination among students.

2. The high reliability module can be implemented to other target groups other than university students.

\section{Conclusions}

Overall, this study was successful in building the Entrepreneurship Career Determination Module (ECDM) using the Cognitive Behavioral Therapy (CBT) approach. The value of overall reliability of this module was .964, whereas the highest reliability value based on the activity was .908 and the lowest was .711. Thus, it can be concluded that ECDM-CBT can be developed and applied in further experimental studies. 


\section{References}

1. Ajzen, I., \& Fishbein, M. (1977). Attitude-Behavior Relations: A Theoretical Analysis and Review of Empirical Research. Psychological Bulletin, 84(5), 888-918.

2. Ajzen, I. (1991). The Theory Of Planned Behavior. Orgnizational Behavior and Human Decision Processes, 50, 179-211.

3. Ajzen, I., \& Fishbein, M. (1988). Theory of reasoned action/Theory of planned behavior. University of South Florida, 2007, 67-98.

4. Ajzen, I. (2002). Perceived Behavioural Control, Self-Efficacy, Locus of Control And The Theory Of Planned Behaviour. Journal of Applied Social Psychology, 32(4), 665-683.

5. Ajzen, I., \& Fishbein, M. (2005). The Influence of Attitudes on Behavior. In The Handbook of Attitudes (pp. 173-221).

6. Ajzen, I. (2015). The Theory of Planned Behaviour Is Alive And Well, And Not Ready To Retire: A Commentary On Sniehotta, Presseau, and Araújo-Soares. Health Psychology Review.

7. Ajzen, I., \& Fishbein, M. (1972). Attitudes and Normative Beliefs as Factors Influencing Behavioral Intentions. Journal of Personality and Social Psychology, 21(1), 1-9.

8. Baharu, K., Mohammed, Z. Y., \& Nita, E. (2011). Entrepreneurial Intention : An Empirical Study of Community College Students in Malaysia. Jurnal Personalia Pelajar, 14, 45-58.

9. Bandura, A. (1977). Self-efficacy: Toward a Unifying Theory of Behavioral Change. Psychological Review, 84(2), 191-215.

10.Bandura, A. (1986). The Explanatory and Predictive Scope of Self-Efficacy Theory. Journal of Clinical and Social Psychology, 4, 359-373.

11.Bandura, A. (1993). Perceived Self-Efficacy in Cognitive Development and Functioning. Educational Psychologist, 28(2), 117-148.

12.Beck Institute for Cognitive Behaviour Therapy.(2016). https://beckinstitute.org/

13.Bidin, Z., Mohd-Shamsudin, F., \& Othman, M. Z. (2012). Applying Theory of Planned Behavior on Entrepreneurial Intent Among Malay Accounting Students. Internasional Journal of ASEAN, 1(1), 49-60.

14.Corey G. (2009). Theory and Practice of Group Counseling. Ed $8^{\text {th. }}$ USA. Thomson Learning.

15.Doll, J. \& Ajzen, I. 1992. Accessibility and Stability of Predictors in the Theory of Planned Behavior. Journal of Personality and Social Psychology, 63(5), 754-765.

16.Esa, A., Suadi, S., \& Daud, N. (2013). Persepsi Pelajar Terhadap Program Kerjaya Di Universiti Tun Hussein Onn Malaysia. Persepsi Pelajar Terhadap Program Kerjaya Di Universiti Tun Hussein Onn Malaysia, $1-9$.

17.Fishbein, M., \& Ajzen, I. (1975). Belief, Attitude, Intention, And Behavior: An Introduction To Theory And Research. Philosophy Rhetoric (Vol. 10).

18.Gerald, C. (2009). Theory and Practice of Counseling and Psychotherapy $9^{\text {th }}$.Thomson Higher Education. USA.

19.Gibson, R. L., \& Mitchell, M. H. (2003). Introduction to Counseling and Guidance. New York New Jersey Merrill Prentice Hall.

20.Judith, S. B. (2011). Cognitive Behaviour Therapy: Basic and Beyond, The Guilford Press A Division of Guilford Publications, Inc. 72 Spring Street, New York.

21.Kuckertz, A., \& Wagner, M. (2010). The Influence of Sustainability Orientation on Entrepreneurial Intentions - Investigating the Role of Business Experience. Journal of Business Venturing, 25(5), 524-539.

22.Krueger, N. F., Reilly, M. D., \& Carsrud, A. L. (2000). Competing Models of Entrepreneurial Intentions. Journal of Business Venturing, 15(5), 411-432.

23.Krueger, N. F \& Carsrud. (1993). Entrepreneurial Intentions: Applying the Theory of Planned Behaviour. Entrepreneurship H Regional Development, 5 (1993). 315-330

24.Kuckertz, A., \& Wagner, M. (2010). The Influence of Sustainability Orientation on Entrepreneurial Intentions - Investigating the Role of Business Experience. Journal of Business Venturing, 25(5), 524-539.

25.Lau, P. L., Aqeel, K., Haslee, S. A. \& Fong, P. C. (2011). The Effectiveness of Career Exploration Program for High School Students.IPEDR Vol.20.226-230.

26.Lukens, E. P., \& McFarlane, W. R. (2004). Psychoeducation as Evidence-Based Practice: Considerations for Practice, Research, and Policy. Brief Treatment and Crisis Intervention, 4, 205-225. 
27.Hakan, M. T., Melis, S .K. \& Emre, S. A. (2015). Guided Discovery with Socratic Questioning (47-53)

28. Melati, I. H., dan Azmawati, N. F. (2017). Teori Kaunseling Dan Psikoterapi. Penerbit Universiti Malaya, Kuala Lumpur.

29.Mohammad, A. S. M. A. \& Fatimah, Y. (2010). Kesan Kelompok Bimbingan Ke Atas Konsep Kendiri - Rakan Sebaya, Daya Tahan Dan Kelangsangan Remaja Pertengahan Yang Sederhana Rendah Konsep Kendiri. Jurnak Psikologi Malaysia, 24, 31-47.

30.Mohd, I. M. (2016). Modul Kesediaan Kerjaya Berdasarkan Teori Cognitive Information Processing (CIP) Jurnalkurikulum \& Pengajaran Asia Pasifik, 59-73.

31.Mohd, I. M. (2017). Kesan Program Kerjaya Psiko-Pendidikan Cognitive Information Processing Terhadap Ketidakfungsian Pemikiran Kerjaya dan Efikasi Kendiri Kerjaya Pelajar Sebuah Intitusi Awam. Tesis Ijazah Doktor Falsafah Universiti yang tidak diterbitkan. Universiti Putra Malaysia.

32.Neukrug, E. (2011). The World of the Counselor: An Introduction to the Counseling Profession. $4^{\text {th }}$ ed. Australia: Brooks/Cole.

33.Norasmah \& Salmah. (2011). Kecenderungan Terhadap Pemilihan Kerjaya Keusahawanan Mengikut Persepsi Peserta Skim Usahawan Siswa. Jurnal Teknologi Malaysia, 56, 47-63.

34.Nur, L., Mohd, A. \& Mohamed, N. (2014). Analisis Kesahan Kandungan Modul Penyesuaian Pemikiran Kerjaya (PPK) berdasarkan Teori Cognitive Information Processing (CIP) JPBU 52-67.

35.Widing, C. \& Milne, A. (2006). Teach Yourself Cognitive Behavioral Therapy. London: Mcgraw- Hill Companies, Inc.

36.Willson, R., Branch, R. (2006). Cognitive Behavioural Therapy for Dummies. Chichester, West Sussex, London: John Wiley \& Sons, Ltd.

37.Young, J. E. (1999). Cognitive Therapy for Personality Disorders: A Schema-Focused Approach 3rd Ed. Sarasota, FL: Professional Resource

38.Zaidatol, Hishamuddin. (2010). Memperkasakan Tekad Keusahawanan Pelajar. Serdang: Penerbit Universiti Putra Malaysia. 